\title{
ANALISIS KUALITAS SALA TERASI
}

\author{
Lucy Fridayati, Rahmi Holinesti, Anni Faridah, dan Wirnelis Syarif \\ Jurusan Ilmu Kesejahteraan Keluarga \\ Fakultas Pariwisata dan Perhotelan Universitas Negeri Padang \\ Email: lucyfridayati@yahoo.co.id
}

\begin{abstract}
ABSTRAK
Penelitian ini bertujuan untuk menganalisis pengaruh penggunaan terasi terhadap kualitas sala lauak yang dihasilkan. Penelitian ini merupakan eksperimen dengan metode rancangan acak lengkap (RAL), yang terdiri dari 3 perlakuan dan 3 ulangan. Hasil uji organoleptik pada kualitas sala terasi bentuk (bulat) bentuk (bulat) skor tertinggi terdapat pada perlakuan 40gr $\left(\mathrm{X}_{2}\right)$ dengan kategori berbentuk bulat, kualitas bentuk (seragam) skor tertinggi terdapat pada perlakuan 0gr $\left(\mathrm{X}_{0}\right)$ dengan kategori seragam, kualitas warna kulit (kuning kecoklatan) skor tertinggi terdapat pada perlakuan 60gr $\left(\mathrm{X}_{4}\right)$ dengan kategori kuning kecoklatan, kualitas warna isi (kuning kecoklatan) skor tertinggi terdapat pada perlakuan $60 \mathrm{gr}\left(\mathrm{X}_{4}\right)$ dengan kategori mendekati kuning kecoklatan, kualitas aroma (terasi) skor tertinggi terdapat pada perlakuan $60 \mathrm{gr}\left(\mathrm{X}_{4}\right)$ dengan kategori mendekati sangat beraroma terasi, kualitas tekstur kulit (renyah) skor tertinggi terdapat pada perlakuan 60gr $\left(\mathrm{X}_{4}\right)$ dengan kategori mendekati renyah, kualitas tekstur isi (berongga) skor tertinggi terdapat pada perlakuan $0 \mathrm{gr}\left(\mathrm{X}_{0}\right)$ dan $40 \mathrm{gr}\left(\mathrm{X}_{2}\right)$ dengan kategori mendekati berongga, kualitas tekstur rasa (gurih) skor tertinggi terdapat pada perlakuan $50 \mathrm{gr}\left(\mathrm{X}_{3}\right)$ dengan kategorigurih, kualitas tekstur rasa (terasi) skor tertinggi terdapat pada perlakuan 60gr $\left(\mathrm{X}_{4}\right)$ dengan kategori mendekati sangat beraroma terasi.Sala terasi memiliki kadar karbohidrat 32,16\%; kadar protein 2,50\%; kadar lemak 16,26\%; kadar air 45,94\%; dan kadar abu 2,54\%.
\end{abstract}

Kata kunci-Sala lauak, Terasi, Kualitas.

\section{PENDAHULUAN}

Pariaman merupakan salah satu wilayah pesisir di Sumatera Barat. Kota Pariaman adalah daerah pariwisata yang terkenal dengan keindahan pantai dan lautnya. Pada umumnya masyarakat disana bermata pencaharian sebagai nelayan. Hasil laut yang diperoleh dijual secara langsung maupun diawetkan terlebih dahulu. Salah satu hasil awetan ikan yang banyak dijumpai adalah ikan asin. Ikan asin banyak dimanfaatkan sebagai bahan utama dalam proses pembuatan sala lauak yang merupakan makanan khas Pariaman.

Sala lauak terbuat dari tepung beras, ikan asin serta bumbu-bumbu lainnya dan digoreng hingga kuning keemasan. Sala lauak merupakan panganan tradisional yang memiliki mutu dan daya saing tinggi dipasaran. Semua kalangan bisa mengkonsumsi dan menikmati sala lauak.Akan tetapi persaingan pasar yang terjadi disaat perekonomian negara yang sedang berkembang membuat sala lauakharus bersaing dengan jajanan modern atau makanan cepat saji. Menurut Evi Heryanti (2009:5)

"Saat ini masyarakat cenderung lebih menyukai makanan cepat saji (fast food) yang tinggi lemak, protein, karbohidrat dan natrium yang jika dikonsumsi secara terus menerus dengan porsi yang berlebihan akan berdampak meningkatnya kecenderungan kelebihan berat badan (overweight) yang merupakan salah satu faktor resiko kejadian penyakit degeneratif".

Berbagai penelitian menunjukkan bahwa perilaku makan yang salah akan menyebabkan masalah gizi dan perilaku makan tersebut dipengaruhi oleh aneka faktor sosial, ekonomi, budaya dan ketersediaan pangan. Analisis data menunjukkan adanya kecenderungan perilaku konsumsi makanan jadi (termasuk minuman) yang semakin meningkat dari tahun ke tahun. Tindakan kecil yang bisa dilakukan untuk mempertahankan panganan tradisional adalah dengan cara memvariasikan atau mengembangkan rasa dari sala lauak tersebut.

Sala lauak biasanya dijadikan kudapan yang dihidangkan dalam keadaan panas. Masyarakat sekitar juga terbiasa mengkonsumsi sala lauak sebagai pendamping makan lontong, makan sate atau dikonsumsi seperti makan gorengan. Berdasarkan pengamatan penulis kudapan ini sangat disukai, mulai dari anak-anak sampai orang dewasa. Bentuknya yang bulat seperti bola pingpong dan memiliki rongga ditengahnya menjadi ciri khas tersendiri.Sala lauak terbuat dari tepung beras yang digonseng, cabe giling, bumbu-bumbu, garam, air dan ikan asinkemudian digorenghingga kuning keemasan. 
Menurut Kamsina dan Inda (2011:1) sala lauak adalah "Makanan tradisional yang rasanya gurih karena dibuat dari tepung beras dan diisi di dalamnya dengan ikan asin, serta irisan daun kunyit, cabe, garam, dan bumbu-bumbu lainnya".

Salah satu bahan utama dari sala lauk adalah ikan asin. Pada saat sekarang ini harga ikan asin semakin lama semakin tinggi.Pedagang mulai mengurangi campuran ikan asin pada pengolahan sala lauak agar mendapatkan keuntungan yang lebih. Sehingga cita rasa yang dihasilkan mulai berkurang, sedangkan ciri khas dari sala lauakadalah ikan asin. Untuk mempertahankan ciri khas dari sala lauakperlu adanya pengkajian dan peningkatan mutu dari kudapan tersebut. Salah satu alternatif yang dapat dilakukan adalah mengganti ikan asin dengan produk hasil pengawetan ikan seperti adalah terasi.

Terasi adalah hasil awetan ikan atau udang yang diolah dan difermentasikan, sebelumnya dilakukan penggilingan dan penjemuran. Menurut SNI 2716.1-2009, SNI 2716.2-2009 dan SNI 2716.3-2009, "Terasi udang adalah produk olahan hasil perikanan dengan menggunakan bahan baku yang mengalami perlakuan fermentasi. Bahan baku utama untuk membuat terasi udang yaitu udang segar dan udang kering".Sedangkan menurut Nova Hariyanto, dkk (2013:14) terasi adalah "Bumbu masak yang dibuat dari udang yang difermentasikan, berbentuk seperti pasta dan berwarna hitam kecoklatan, kadang ditambahi bahan pewarna sehingga menjadi kemerahan". Terasi sangat mudah ditemukan baik dipasaran maupun diwarung-warung dengan harga yang relatif murah. Terasi memiliki bau yang khas dan pemakaiannya pun sedikit dalam pengolahan makanan. Sayangnya terasi hanya digunakan sebagai bahan penyedap makanan sayuran, sambal, rujak dan sebagainya, namun terasi dapat disimpan sampai berbulan-bulan.

Pada penelitian ini penulis mencoba memvariasikan bahan protein pada pembuatan sala lauakyaitu mengganti ikan asin dengan terasi. Selain untuk meningkatkan mutu dari sala lauaktersebut, juga salah satu langkah untuk memvariasikan rasa sala lauakdan menciptakan karya baru yang bersumber dari panganan tradisional. Pada bulan April tahun 2016 penulis telah melakukan pra penelitian dan didapatlah hasil bahwa dengan penggunaan terasi aroma yang dihasilkan lebih tajam dibandingkan dengan penggunakan ikan asin. Pemanfaatan dari hasil olahan ikan lainnya pun akan berguna, karena selama ini terasi hanya dijadikan bumbu masak atau pelengkap rasa dari suatu masakan.

Berdasarkan pembahasan di atas dapat disimpulkan bahwa pembuatan sala lauak saat sekarang ini masih menggunakan ikan asin yang harganya semakin lama semakin tinggi, hal tersebut membuat para pedagang mendapatkan keuntungan yang tipis.

Penelitian ini bertujuan untuk menganalisis kualitas sala terasi yang dihasilkan melalui uji organoleptik, dari segi bentuk, warna, aroma, rasa dan tekstur. Disamping itu, juga untuk menganalisis kandungan gizinya. Manfaat yang diharapkan adalah untuk meningkatkan variasi olahan sala, serta meningkatkan pengetahuan masyarakat terhadap kandungan gizi yang terdapat pada sala terasi.

\section{METODOLOGI PENELITIAN}

\section{A. Jenis Penelitian}

Jenis penelitian yang dilakukan adalah eksperimen murni (true eksperiment).

\section{B. Lokasi dan Jadwal Penelitian}

Penelitian ini dilaksanakan pada bulan November 2016 di Workshop Tata Boga, Jurusan Ilmu Kesejahteraan Keluarga, Fakultas Pariwisata dan Perhotelan, Universitas Negeri Padang. Serta Laboratorium Teknologi Hasil Pertanian, Fakultas Teknologi Pertanian, Universitas Andalas Padang.

\section{Prosedur Penelitian}

1. Tahap Persiapan

Sebelum proses pengolahan dilaksanakan, bahan-bahan yang harus dipersipakan terlebih dahulu dalam pembuatan sala terasi adalah tepung beras, terasi, air, minyak goreng, cabe merah giling, bawang merah, bawang putih, kunyit, jahe, daun kunyit, daun bawang dan garam. Sedangkan peralatan yang dibutuhkan dalam penelitian ini adalah wajan, timbangan, bowl stainless steel, piring email, talenan, ayakan, pisau, sendok kayu, sendok makan, dan blender. 


\section{Tahap Pengolahan}

Pada penelitian ini, resep standar yang digunakan adalah resep dari Wulan $(2015: 23)$ yaitu tepung beras (500 gr), ikan asin (40 gr), bawang merah (12 gr), bawang putih ( 24 gr), cabe merah giling (40 gr), jahe (12 gr), kunyit (4 gr), daun bawang (20 gr), daun kunyit (8 gr), garam (4 gr), air (1.000 gr) dan minyak goreng (1.000 gr). Sedangkan untuk resep penelitian, terasi yang digunakan sebagai pengganti ikan asin sebanyak $30 \mathrm{gr}, 40 \mathrm{gr}, 50$ gr dan 60 gr.

\section{Tahap Penilaian}

Setelah sala terasi digoreng, kemudian diberi kode sampel, kemudian dilanjutkan dengan uji organoleptik dengan cara mengamati, mencium, mencicipi, dan meraba sampel. Respon yang dirasakan oleh panelis dituliskan pada lembaran uji organoleptik dengan memberi tanda ceklis $(\sqrt{ })$.

\section{Analisis Data}

1. Uji organoleptik

Data hasil uji organoleptik yang diperoleh ditabulasi, selanjutnya dilakukaan analisis varian (ANAVA). Jika berbeda nyata dilanjutkan dengan uji duncan (DNMRT).

\section{Kandungan gizi}

Sampel terbaik hasil uji organoleptik, dilanjutkan dengan analisis kandungan gizi dalam bentuk uji proksimat, yang terdiri dari: kadar karbohidrat, kadar protein, kadar lemak, kadar abu, dan kadar air.

\section{HASIL DAN PEMBAHASAN}

\section{A. Hasil Penelitian}

Berdasarkan uji organoleptik (uji jenjang) yang telah dilakukan terhadap kualitas sala terasi yang meliputi kualitas bentuk (bulat), bentuk (seragam), warna kulit (kuning kecoklatan),warna isi (kuning kecoklatan), aroma (terasi), tekstur kulit (renyah), tekstur isi (berongga), rasa (gurih) dan rasa (terasi), maka diperoleh hasil penelitian yang disajikan pada Gambar 1.

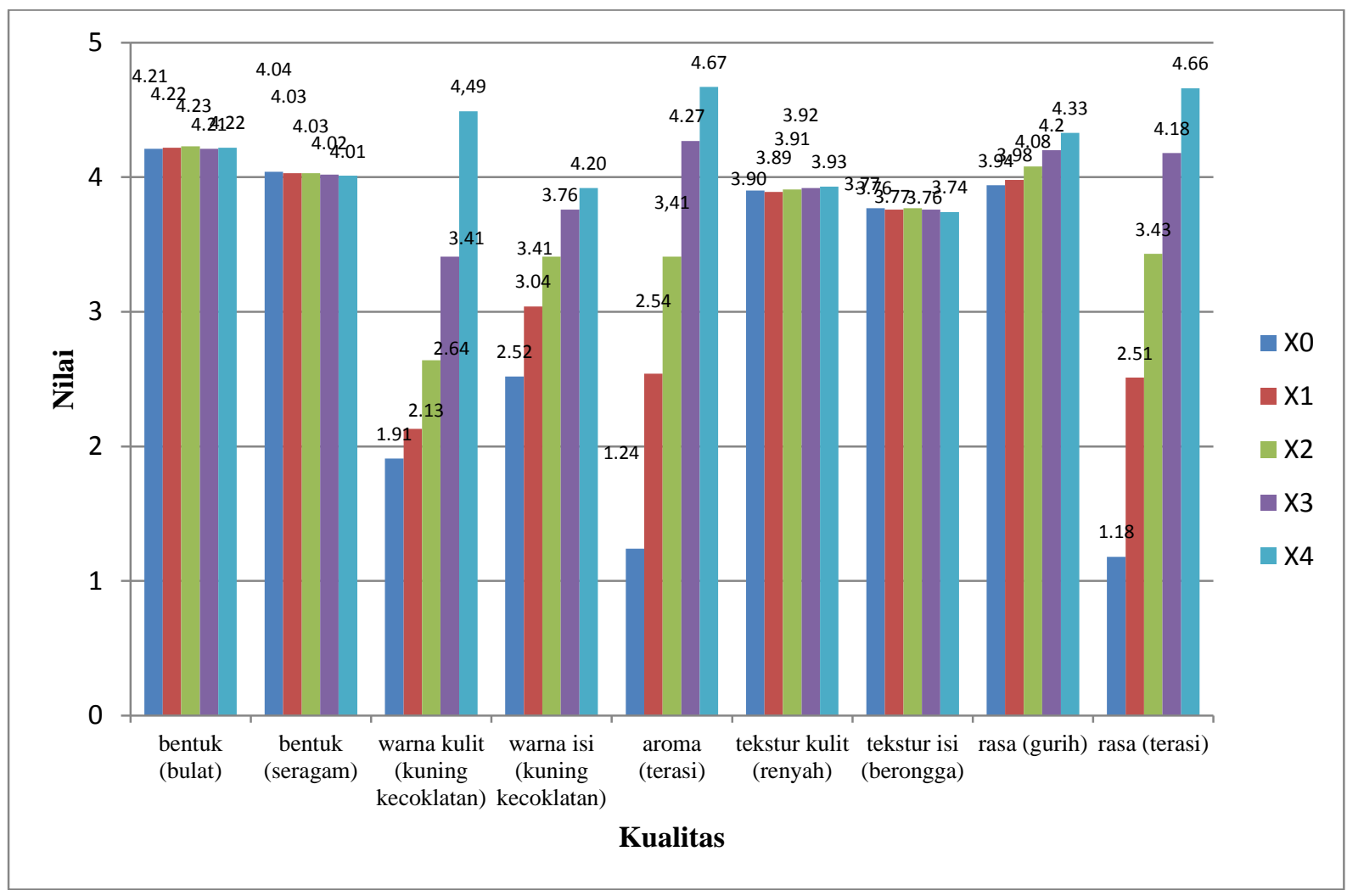

Gambar 1. Rata-Rata Skor Kualitas Sala Terasi 
Berdasarkan Gambar 1, dapat dijelaskan bahwa nilai rata-rata uji jenjang untuk kualitas sala terasi bentuk (bulat) skor tertinggi terdapat pada perlakuan 40gr $\left(\mathrm{X}_{2}\right)$, bentuk (seragam) skor tertinggi terdapat pada perlakuan 30gr $\left(\mathrm{X}_{1}\right)$ dan $40 \mathrm{gr}\left(\mathrm{X}_{2}\right)$, warna kulit (kuning kecoklatan) skor tertinggi terdapat pada perlakuan 60gr $\left(\mathrm{X}_{4}\right)$, warna isi (kuning kecoklatan) skor tertinggi terdapat pada perlakuan 60gr $\left(\mathrm{X}_{4}\right)$,aroma (terasi) skor tertinggi terdapat pada perlakuan 60gr $\left(\mathrm{X}_{4}\right)$, tekstur kulit (renyah)skortertinggi terdapat pada perlakuan $60 \mathrm{gr}\left(\mathrm{X}_{4}\right)$, tekstur isi (berongga) skor tertinggi terdapat pada perlakuan $0 \mathrm{gr}\left(\mathrm{X}_{0}\right)$ dan 40gr $\left(\mathrm{X}_{2}\right)$, tekstur rasa (gurih) skor tertinggi terdapat pada perlakuan 60gr $\left(\mathrm{X}_{4}\right)$ dan rasa (terasi) skor tertinggi terdapat pada perlakuan $60 \mathrm{gr}\left(\mathrm{X}_{4}\right)$.

\section{B. Pembahasan}

Setelah melakukan penelitian sebanyak tiga kali pengulangan dengan 5 macam perlakuan, maka terlihat hasil dari sala terasi yang meliputi kualitas bentuk (bulat), bentuk (seragam), warna k u 1 i t (kuning kecoklatan), warna isi (kuning kecoklatan), aroma(terasi),tekstur kulit (renyah), tekstur isi (berongga), rasa (gurih) dan rasa (terasi). Berikut ini akan dibahas kualitas sala berdasarkan masingmasing indikator:

\section{Uji Jenjang Bentuk (Bulat) Sala Terasi}

Hasil analisis ANAVA menyatakan Ha ditolak yang artinya tidak terdapat pengaruh kualitas bentuk (bulat) terhadappenggunaan terasi pada sala. Bentuk (bulat) dari sala terasi bisa dilihat dari keserasian bentuk sala. Hasil analisisANAVA menunjukkan kualitas bentuk (bulat) dengan nilai ratarata terbaik adalah 4,23 pada variabel X2 kualitas bentuk. Bentuk diperoleh dari adonan, yaitu dari cairan dan tepung beras yang digunakan.

Bentuk merupakan tampilan dari sebuah makanan. Bentuk sering disebut penampilan dari suatu makanan, penampilan sangat diperlukan dalam makanan, karena merupakan kriterasia penampilan (Shadily, 1976: 96). Sejalan dengan itu menurut Onong (1984: 54) "Sebuah bentuk dapat diciptakan dengan tangan bebas atau memakai alat pembantu". Bentuk makanan dapat di peroleh dari alat berupa cetakan maupun kreatifitas dari pembuatnya. Sala terasiyang dihasilkan berbentuk bulat, yang dibentuk menggunakan tangan.

\section{Uji Jenjang Bentuk (Seragam) Sala Terasi}

Hasil analisis ANAVA menyatakan Ha ditolak yang artinya tidak terdapat pengaruh kualitas bentuk (seragam) terhadappenggunaan terasi pada sala. Bentuk (seragam) dari sala terasi bisa dilihat dari keseragaman bentuk sala. Hasil analisisANAVA menunjukkan kualitas bentuk (seragam) dengan nilai rata-rata terbaik adalah 4,04 pada variabel X0. Keseragaman bentuk dapat dilihat dari sala terasi tersebut. Hal ini sejalan dengan pendapat Helva (2015: 66) "Keseragaman bentuk adalah keserasian antar sala yang dihasilkan tanpa terjadinya penurunan kualitasnya".

\section{Uji JenjangWarna Kulit (Kuning Kecoklatan) Sala Terasi}

Hasil analisis ANAVA menyatakan Ha diterasimayangartinya terdapat pengaruh kualitas warna kulit (kuning kecoklatan) terhadappenggunaan terasi pada sala. Warna pada sala terasi ini dapat dipengaruhi oleh bahan yang digunakan untuk setiap perlakuan. Semakin tinggi perbandingan penggunaan terasi yang digunakan maka akan memberikan pengaruh terhadap warna sala itu sendiri.

Warna merupakan salah satu faktor penting dalam penentuan kualitas makanan. Warna dapat digunakan sebagai indikator kematangan suatu makanan. Warna kuning kecoklatan yang dihasilkan pada sala terasi dikarenakan adanya pengaruh dari pemakaian bahan yaitu terasi, kunyit dan cabe giling. Hasil analisisANAVA menunjukkan kualitas (kuning kecoklatan) dengan nilai rata-rata terbaik adalah 4,49 pada variabel X4.

\section{Uji JenjangWarna Isi (Kuning Kecoklatan) Sala Terasi}

Hasil analisis ANAVA menyatakan Ha diterasimayangartinya terdapat pengaruh kualitas warna isi (kuning kecoklatan) terhadap penggunaan terasi pada sala. Warna kuning kecoklatan yang dihasilkan pada sala terasi dikarenakan adanya pengaruh dari pemakaian bahan yaitu terasi, kunyit dan cabe giling. 
Hasil analisisANAVA menunjukkan kualitas (kuning kecoklatan) dengan nilai rata-rata terbaik adalah 3.92 pada variabel X4.

Hasil ANAVA menyatakan Ha diterima yang artinya terdapat pengaruh kualitas warna isi (kuning kecoklatan) terhadap penggunaan terasi pada sala. Hal ini disebabkan oleh udang rebon yang memiliki aroma yang khas, semakin banyak substitusi udang rebon maka semakin tinggi pula aroma yang ditimbulkan pada sala, dan bahan lainnya seperti garam dalam pengolahan akan mampu untuk meningkatkan aroma tersebut. Menurut Herliani (2013: 17) "Makanan yang beraroma harum di tentukan oleh pemakaian bahan yang berkualitas". Dari uraian di atas dapat disimpulkan bahwa bau harum sala dikeluarkan dari aroma udang rebon. Hal ini dapat dilihat dari hasil analisis ANAVA menunjukkan kualitas aroma dengan nilai rata-rata terbaik adalah 4,20 pada variabel X4.

\section{Uji JenjangAroma(Terasi) Sala Terasi}

Hasil ANAVA menyatakan Ha diterima yang artinya terdapat pengaruh kualitas aroma (terasi) terhadap penggunaan terasi pada sala. Hal ini disebabkan oleh terasi yang memiliki aroma yang khas, semakin banyak substitusi terasi maka semakin tinggi pula aroma yang ditimbulkan pada sala, dan bahan lainnya seperti garam dalam pengolahan akan mampu untuk meningkatkan aroma tersebut. Hal ini dapat dilihat dari hasil analisis ANAVA menunjukan kualitas aroma dengan nilai rata-rata terbaik adalah 4,67 pada variabel X4.

\section{Uji JenjangTekstur Kulit (Renyah) Sala Terasi}

Hasil analisis ANAVA menyatakan Ha ditolak yang artinya tidak terdapat pengaruh kualitas tekstur kulit (renyah) penggunaan terasi pada sala. Tekstur merupakan penilaian keseluruhan terhadap bahan makanan yang dirasakan oleh mulut. Hal ini dapat dilihat dari hasilanalisisANAVA menunjukkan kualitas tekstur dengan nilai rata-rata terbaik adalah 3.93 pada variabel X4.

\section{Uji Jenjang Tekstur Isi (Renyah) Sala Terasi}

Hasi analisis ANAVA menyatakan Ha ditolak yang artinya tidak terdapat pengaruh kualitas tekstur isi (berongga) penggunaan terasi pada sala. Tekstur merupakan penilaian keseluruhan terhadap bahan makanan yang dirasakan oleh mulut. Hal ini dapat dilihat dari hasilanalisisANAVA menunjukkan kualitas tekstur dengan nilai rata-rata terbaik adalah 3.77 pada variabel X2.

\section{Uji JenjangRasa (Gurih) Sala Terasi}

HasilANAVA menyatakanHa diterasimayangartinya terdapat pengaruh kualitasrasa (gurih) terhadap penggunaan terasi pada sala. Menurut Wisnu (2007: 76) "Rasa adalah tanggapan indra pengecap terhadap rangsangan seperti rasa manis, asin, manis, pahit dan asam". Rasa yang dihasilkan sala terasi adalah rasa gurih karenadipengaruhi daripemakaian terasi dan bumbu- bumbu lainnya, semakin banyak terasi yang digunakan sala yang dihasilkan semakin gurih. Hal ini dapat dilihat dari hasilanalisisANAVA kualitas rasa dengan nilai rata-rata terbaik adalah 4.33 pada variabel X4.

\section{Uji Jenjang Rasa (Terasi) Sala Terasi}

HasilANAVA menyatakanHa diterasimayangartinya terdapat pengaruh kualitas rasa (terasi) terhadap penggunaan terasi pada sala. Rasa yang dihasilkan sala terasi adalah rasa terasi, semakin banyak terasi yang digunakan sala yang dihasilkan semakin berasa terasi. Disamping itu garam juga membantu membangkitkan rasa pada sala terasi.

Fungsi garam adalah sebagai bahan untuk menarik rasa dan aroma dari bahan-bahan lain yang digunakan untuk membuat suatu produk makanan. Hal ini sesuai dengan pendapat Helva (2015: 102) yang menyatakan bahwa "Garam berfungsi memberikan aroma dan rasa pada sala", dan didukung oleh pandapat Wheat Associates (1983: 15) bahwa "garam adalah bahan utama untuk mengatur rasa. Garam akan membangkitkan rasa pada bahan-bahan lainnya dan membantu membangkitkan harum dan meningkatkan sifat-sifat makanan". Hal ini dapat dilihat dari hasilanalisisANAVA menunjukkan kualitas rasa dengan nilai rata-rata terbaik adalah 4.66 pada variabel $\mathrm{X} 4$. 


\section{Kandungan Gizi}

Berdasarkan analisis terhadap kandungan gizi, diketahui bahwa : sala terasi memiliki kadar karbohidrat 32,16\%; kadar protein 2,50\%; kadar lemak 16,26\%; kadar air 45,94\%; dan kadar abu $2,54 \%$. Hal ini menunjukkan bahwa, salaterasi memiliki kandungan gizi yang cukup dan baik untuk kesehatan, dapat diberikan sebagai makanan selingan yang bergizi, terutama bagi balita dan anak-anak usia sekolah.

\section{Kesimpulan}

\section{KESIMPULAN DAN SARAN}

Berdasarkan penelitian yang telah dilakukan, diperoleh kesimpulan sebagai berikut:

1. Hasil uji organoleptik menunjukkan hasil terbaik terdapat pada perlakuan X4 dengan kategori: berbentuk bulat dan seragam, warna kuning kecoklatan, beraroma terasi, tekstur renyah dan berongga, serta memiliki rasa gurih.

2. Hasil analisis terhadap kandungan gizi menunjukkan bahwa : kadar karbohidrat $32,16 \%$; kadar protein 2,50\%; kadar lemak 16,26\%; kadar air 45,94\%; dan kadar abu 2,54\%.

\section{Saran}

Setelah melakukan penelitian ini peneliti dapat memberikan saran bagi pihak-pihak terkait dalam bidang Tata Boga yaitu : Bagi mahasiswa agar lebih bisa mengembangkan makanan tradisional yang ada disekitar kita supaya tidak kalah bersaing dengan makanan modern saat ini. Bagi Jurusan Ilmu Kesejahteraan Keluarga semoga penelitian ini bisa menjadi bahan untuk pengembangan yang lebih lanjut.

\section{DAFTAR PUSTAKA}

Anni Faridah, Kasmita, Asmar Yulastri, dan Liswarti Yusuf. (2008).Patiseri Jilid 1 dan 3. Jakarta: Depdiknas.

Anonim. 2009. Pengertian Terasi (diunggah tanggal 30 Maret 2016)

Fadiati, Ari. 2011. Mengelola Usaha Jasa Boga Yang Sukses: Jakarta. PT. Remaja Rosdakarya

Febriana, Ana, dkk. 2014. Evaluasi Kualitas Gizi, Sifat Fungsional dan Sifat Sensoris Sala Lauak dengan Variasi Tepung Beras Sebagai Akternatif Makanan Sehat. (diunggah tanggal 29 Maret 2016).

Hariyanto, Nova, dkk. 2013. Upaya Peningkatan Kualitas dan Produksi Pencacahan Udang Rebon Menjadi Terasi dengan Aplikasi Mesin Extruder. (diunggah tanggal 14 Juni 2016).

Helva Wahyuni. (2015). Standarisai Sala Lauak di Kanagarian Ulakan. Skripsi. Padang: UNP.

Heryanti, Evi. 2016. Kebiasaan Makan. (diunggah 28 Mei 2016)

Kamsina dan Inda Three Anova. 2011. Pengaruh Jenis Tepung dan Pengolahan Ikan Terhadap Mutu Tepung Sala Lauak. (diunggah 29 Maret 2016).

Resmiati, dkk. 2003. Pengasinan Ikan Terasi dan Kelayakannya di Desa Karanghantu Serang. Bandung: Universitas Padjadjaran.

Sugiyono. (2010). Metode Penelitian Kuatitatif, Kualintatif dan R\&D. Bandung: Alfabeta.

Tuti Soenardi. 2013. Teori Dasar Kuliner. Jakarta: PT Gramedia Pustaka.

Wahyuni, Helva. 2015. Standarisasi Resep Sala Lauak Di Kanagarian Ulakan Kabupaten Padang Pariaman. Universitas Negeri Padang. Padang.

Wulan Puspita Sari. (2015). Kualitas dan Daya Terasima Sala Lauk dengan Penambahan Bayam dan Ikan Segar Sebagai Makanan Anak Balita. Skripsi. Padang: UNP. 